\title{
A Feminist Scientist Shouts Conveying I Am Here
}

\section{Montaser LM*}

Department of Clinical Pathology, Faculty of Medicine, Menoufia University, Egypt

*Corresponding author: Laila Mahmoud Montaser, Department of Clinical Pathology, Faculty of Medicine, Menoufia University, Chair of Stem Cell, Regenerative Medicine, Nanotechnology and Tissue Engineering (SRNT) Research Group, Egypt, Email: lailamontaser@gmail.com

\section{Editorial}

Volume 4 Issue 1

Received Date: January 07, 2020

Published Date: January 21, 2020

DOI: $10.23880 /$ jes-16000134

\section{Editorial}

I will narrate my successful experience and research in SPIE 2015 at San Diego, California, USA on a scientific and national level.

An Egyptian female scientist's perspective taking place in San Diego, SPIE conference 2015 was a very successful experience concerning the application of Nano scaffolds and stem cell therapy in liver tissue engineering.

On the background of attending the International Conference SPIE Nanoscience + Engineering, Biosensing and Nanomedicine VIII, 09-13 Aug. 2015 at San Diego, California, USA, on 23 Jul 2015, I received an invitation via my email to attend Women in Optics Presentation and Reception, Monday 10 August 5:00 PM-6:30 PM, Marriott Marquis, Marina and the exact words were "Join us for an early evening of networking and inspiration, this evening will feature reports on International Year of Light activities from around the world, the panel will be followed by a reception, offering the opportunity to meet the speakers and connect with your peers".

The morning of that Monday 10 August, 2015, was the appointment of contributing my oral presentation at the conference titled "NANO scaffolds and stem cell therapy in liver tissue engineering" [1], where I presented current and emergent approach based on stem cells in the field of liver tissue engineering for specific application as the combination of stem cells and tissue engineering opens new perspectives in tissue regeneration for stem cell therapy because of the potential to control stem cell behavior with the physical and chemical characteristics of the engineered scaffold environment. I explained the process of tissue regeneration in liver tissue engineering. For therapeutic application of tissue engineering, engineered tissue was grown in vitro and for experimental application transplanted into an animal liver fibrosis model as shown in Figure 1.

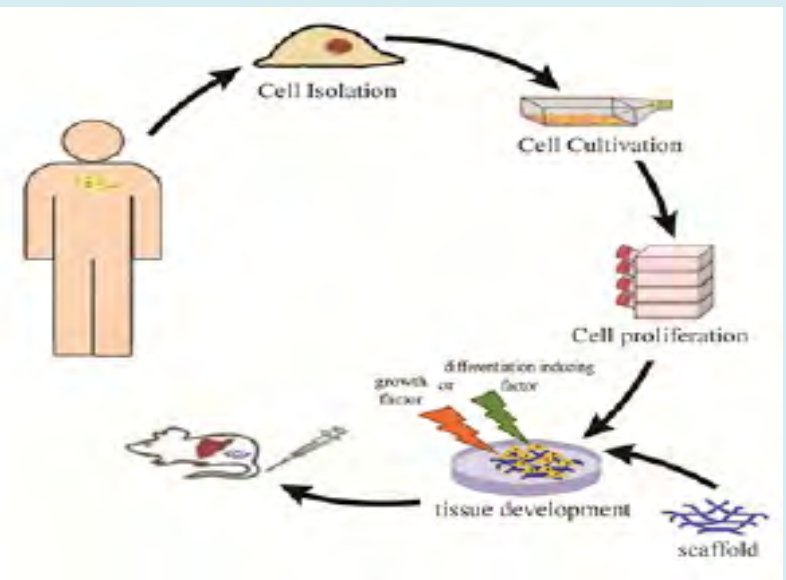

Figure 1: A schematic representation of the process of tissue regeneration in liver tissue engineering. 


\section{Journal of Embryology \& Stem Cell Research}

Figure 1 provided a schematic representation of the process of tissue regeneration in liver tissue engineering. Human cells were harvested from a patient and after in vitro cell culture; cells were seeded onto scaffolds with medium containing chemical stimuli, such as growth factors and differentiation-inducing factors. Scaffolds were threedimensional (3D) matrices that support cellular growth processes, such as cell adhesion, migration, proliferation, and differentiation, by which cells were colonized onto the scaffold. The cell-colonized scaffold was then implanted into the animal model, to regenerate bio-compatible, immunocompatible, and bio functional tissues or organs inside the animal model body. Cells and scaffolds were essential to regenerate new tissues with tissue engineering. Cells become the primary component of the engineered tissue and the scaffold provides cells with an appropriate physical and chemical environment where they can attach to the surface of the scaffold, migrate through the scaffolds' pores, and then proliferate [2-12].

The evening of that day I was on time there to attend Women in Optics Presentation and Reception, where on the stage sited a group of female scientists from around the world from Ireland, Canada, USA, and others. Behind them a big screen was hanged for their presentations. Every female scientist on the stage contributed an oral presentation with some figures on the screen. The last one presented her talk with some slides, the last slide was a big map of the world, where she said on this map the countries with the yellow color we know nothing about the activities of their female scientists in our field. Exactly at the center of the map, strangely my country Egypt was yellow in color!! Then they opened the discussion. One man scientist from Costa Rica was attending the meeting and as his country was in yellow color; he extensively proceeded to defend about women scientists in his homeland, then he sat down without reaching women' expectations in his defense.

Then I asked for the speech, I said softly, literally "I am an Egyptian Professor from Egypt, I came from Egypt, and this morning I contributed an oral presentation at the conference, add Egypt on the map". I was surprised by a storm of applause from all the attendees, which caused hilarity and a mood in the hall with the laughter of the ladies on the podium in response to these twenty seven words especially, that slide to the world map was still on the screen. The Chairwoman asked me if there were a large number of female scientists like me in Egypt I answered positively. Then she started to apologize for what happened because they prepared their speeches many months and did not touch all the female scientists' presentations. At the reception, a large number of scientists were speaking with me. On the days that followed, everyone who watched me would cheer, yes, you are the Egyptian scientist they announced this to us at the conference.

It is well known that Egypt is a country full of scientists and women scientists' expertise in all the scientific and medical fields, with the highest percentage and highest scientific degrees not only in Egypt but also in all the Arab World and the Middle East, throughout Africa.

In fact, it was a woman scientist outcry of spontaneous passion reporting I am here; I said that from my heart, for this reason the outcry reached the hearts of all those present.

\section{References}

1. Montaser LM, Fawzy SM (2015) NANO scaffolds and stem cell therapy in liver tissue engineering, pp: 8.

2. Montaser LM, Metwally, HG, Elbasuoni, MA, Tawfeek GA (2013) In Vitro Differentiation of Human Adult Stem Cells into Hepatic Lineage Cells. Presented at: $9^{\text {th }}$ Royan International Congress on Stem Cell Biology and Technology, Tehran, Iran. Cell Journal 15(1): 53-53.

3. Montaser LM, Fawzy SM (2014) Promising cell therapy achieves improvement outcomes. Presented at: 43 ISEH 2014, 21-24 August 2014, Montreal, Canada, Aug. 2014. Experimental Hematology-J for hematology, stem cell biology and transplantation 42(8): S53.

4. Montaser LM, Metwally HG, Elbasuoni MA, Tawfeek GA (2014) Human mesenchymal stem cells be a potential source for cell therapy in liver disorders. Int $\mathrm{J}$ of Biotechnol \& Bioengineering 8(9): 6.

5. Montaser LM, Abbassy HA, Fawzy SM (2016) Articular cartilage tissue engineering with plasma-rich in growth factors and stem cells with Nano scaffolds. Presented at: SPIE Nanoscience+Engineering 28 Aug-01 Sept. 2016, San Diego, California, USA. Proc. SPIE, Biosensing and Nanomedicine 9930: 16.

6. Montaser LM, El Azab DS, Tawfeek GA, Saied SA (2016) Liver Regeneration in A Carbon Tetrachloride Induced Acute Liver Failure Model: Do Bone Marrow-Derived Cells Contribute? Cell journal 18(1): 50-50.

7. Montaser LM, Fawzy SM (2016) Nanotechnology to Drive Stem Cell Commitment in Liver Tissue Engineering. Cell Journal 18(1): 50-50.

8. Montaser LM, Fawzy SM (2018) Hepatic Tissue Engineering and Regenerative Medicine. Presented at World Biotechnology Congress 2018, Berlin, Germany.

9. Montaser LM and Fawzy SM (2018) Nanotechnology for articular cartilage regeneration. Presented at 


\section{Journal of Embryology \& Stem Cell Research}

International Conference on Nanotechnology and Nanoengineering, July 16-18, 2018, Paris, France. J Nanomater Mol Nanotechnol 7: 1.

10. Montaser LM, El Azab DS, Hassan EA (2019) Mesenchymal Stem Cells Applications on the Chronic Liver Disease. MD Thesis in Clinical Pathology Department, Faculty of Medicine, Menoufia Univerisity, Egypt.
11. Montaser LM, Fawzy SM (2019) Novelties in Cartilage Tissue Regeneration using Nano Scaffolds. Int J Mater Sci Res 1(1).

12. Montaser LM, El Azab DS, Tawfeek GA, Saied SA (2019) The Role of stem cells in a model of hepatic regeneration. Int J Lab Hematol 41(S2): 122-122. 